\title{
RANCANG BANGUN APLIKASI GATTO FRIENDS DENGAN METODE PROFILE MATCHING BERBASIS ANDROID (STUDI KASUS UNDIP CAT LOVERS SEMARANG)
}

\author{
Humam Alif Subhi, Yasni Djamain, M.Farid Rifai \\ Program Studi Sarjana Teknik Informatika, Sekolah Tinggi Teknik PLN Jakarta \\ Jalan Lingkar Luar Barat Menara PLN Cengkareng Jakarta Barat \\ e-mail: humamalif9@gmail.com, yasni@sttpln.ac.id, mfarid@yahoo.com
}

\begin{abstract}
ABSTRAK
Penelitian ini bertujuan untuk merancang aplikasi pencarian pasangan kucing yang sesuai prosedur Dokter hewan dan asosiasi perkumpulan kucing. Metode sistem pendukung keputusan yang digunakan yaitu Profile Matching dengan proses membandingkan antara kompetensi individu kedalam kompetensi kelompok sehingga dapat diketahui perbedaan kompetensinya, Metode Pengembangan perangkat lunak yang digunakan adalah Metode Multimedia Luther dan Perancangan Aplikasi menggunakan Unified Modelling Language. Data kucing yang digunakan untuk riset aplikasi yaitu pada komunitas UNDIP cat lovers dengan menggunakan uji coba metode Black Box. Diharapkan hasil penelitian ini menunjukan bahwa aplikasi pencarian pasangan kucing dapat membantu para pecinta kucing untuk menemukan mitra kawin untuk kucing peliharaan yang dimiliki adapun kecocokan dengan pemilik hewan maupun peliharaan dan berinteraksi dengan pemilik kucing peliharaan lain di sekitar yang lebih efisien,cepat dan terkomputerisasi.
\end{abstract}

Kata Kunci: Kucing, Sistem Pendukung Keputusan, Profile Matching, Android

\section{ABSTRACT}

The aim of this research is to design the cat couple search application according to Veterinarian procedure and association of cats association. The method of decision support system used is Profile Matching with the process of comparing the individual competencies into the group's competence so as to know the difference of competence, Software Development Method used is Luther Multimedia Method and Application Design using Unified Modeling Language. Cat's data used for research application that is in UNDIP cat lovers community by using Black Box method test. It is hoped that the results of this study show that cat search apps can help cat lovers find mating partners for pet cats that have a match with pet and pet owners and interact with other pet owners around the more efficient, fast and computerized.

Keyword: Cat, Decision Support System, Profile Matching, Android

\section{PENDAHULUAN}

Hewan kesayangan merupakan hewan yang sangat menguntungkan untuk dikembangbiakkan dengan berbagai tujuan dan dapat memberikan sumbangan untuk kebahagiaan manusia. Salah satu hewan kesayangan yang perlu mendapat perhatian untuk dipelihara dan dikembangbiakkan adalah kucing. Sebagai hewan kesayangan, kucing mempunyai daya tarik tersendiri karena bentuk tubuh, mata dan warna bulu yang beraneka ragam. Dengan kelebihan-kelebihan tersebut, maka kucing dapat dikembangkan dan dibudidayakan (Ensiklopedi Indonesia, 1988).

Pada tahun 2006, Sparkes, AH. K. Rogers, mencoba untuk meneliti tentang periode kehamilan pada kucing. Sampel yang dipakai adalah 1.056 anak kucing dari 14 jenis kucing yang berbeda dan dari 942 peternak yang berbeda. Hal ini bertujuan karena ada berbagai variabel yang mempengaruhi masa kehamilan pada kucing. Peneliti berusaha menyelidiki variabel apakah yang mungkin mempengaruhi perbedaan periode kehamilan pada kucing berdasarkan statistik. Dengan menggunakan analisis matematis, para peneliti mampu untuk menentukan faktor determinan yang akan membantu peternak untuk memprediksi masa kehamilan dengan lebih baik lagi. 7,2\% dari semua anak kucing yang lahir mati, bervariasi sesuai dengan jenis kucing. Berat rata-rata bayi kucing bervariasi berdasarkan jenisnya. Rata-rata jumlah 4,6 anak kucing yang dilahirkan juga bervariasi secara signifikan berdasarkan jenis kucing (Suri, 2015).

Para pemilik kucing yang ingin memilihkan jodoh bagi kucing kesayangannya untuk mendapatkan keturunan yang diinginkan oleh pemilik, namun saat pemilik datang langsung ke petshop ternyata sedang tidak ada kucing yang dapat dipilih untuk di jodohkan, atau di kawinkan sesuai keinginan pemilik hal ini menyebabkan kekecewaan pada pemilik kucing yang sudah datang untuk mencari kucing yang dapat dijodohkan untuk kucing dari pemilik tersebut.

Dengan harapan dapat membantu pemilik kucing dalam bertukar informasi untuk mencarikan jodoh kucingnya dengan baik agar didapatkan peranakan yang sesuai dengan ras kucing tersebut dan untuk petshop agar lebih mengembangkan.

Perkembangan yang sangat pesat terhadap media sosial akhir-akhir ini dapat menjadi topik hangat untuk dibahas karena banyak orang yang 
memakai media sosial namun mereka kurang memahami media sosial itu sendiri.

Untuk itu perlu sekiranya sebuah system yang menampung semua informasi mengenai pemilik kucing secara detail dengan adanya data yang detail ini dapat mudah untuk mengkawinkan kucing dengan estimasi waktu dan ketepatan untuk berkembang biak berdasar kriteria kucing .

\section{LANDASAN TEORI}

\subsection{Tinjauan Pustaka}

1. Penerapan metode profile matching untuk memberikan kelayakan pemberian kredit pada pnpm mandiri kota Banjarmasin.

Sistem program yang dibuat adalah software profile matching yang berfungsi sebagai alat bantu untuk mempercepat proses matching antara profil jabatan (soft kompetensi jabatan) dengan profil karyawan (soft kompetensi karyawan) sehingga dapat memperoleh informasi lebih cepat, baik untuk mengetahui gap kompetensi antara jabatan dengan pemegang jabatan maupun dalam pemilihan kandidat yang paling sesuai untuk suatu jabatan (ranking kandidat). Gap yang dimaksud disini adalah perbedaan atara profil jabatan dengan profil karyawan atau bisa ditunjukan pada rumus :

Gap = Profil KSM - Profil Pencapian

Penelitian ini membuat Sistem yang dibangun dapat digunakan untuk menyeleksi pemohon yang lebih baik, sehingga dapat membantu pihak yang berwenang dalam mengambil keputusan yang sesuai dengan kriteria yang ada. Dengan Menggunakan metode Profile Matching dalam menyelesaikan permasalahan pemberian kredit yang mempunyai kriteria-kriteria yang menghasilkan peran-kingan,sehingga mrmudahkan pihak yang berkepentingan dalam menyimpulkan pemohon yang terpilih dalam keputusan pemberian kredit yang layak (Angkasa, 2016).

2. Rancang bangun aplikasi forum komunitas berbasis web (studi kasus : pecinta kucing)

Untuk mengetahui masalah yang terjadi pada forum diskusi pecinta kucing sebelumnya, maka digunakan metode kerangka PIECES sebagai dasar untuk memperoleh pokok-pokok permasalahan yang lebih jelas dan spesifik. Kemudian berdasarkan hasil dari analisa ini dapat dirancang usulan-usulan untuk diterapkan pada sistem yang baru. Hal ini juga untuk mengetahui alasan dari perubahan sistem saat ini dengan tepat (Sukma, 2015).

\section{Sistem pendukung keputusan kenaikan jabatan pada PT.SYSMEX menggunakan metode profile matching.}

Sesuai dengan peraturan yang telah ditetapkan PT. Sysmex dalam melakukan proses kenaikan pangkat jabatan, maka diperlukan kriteriakriteria untuk menentukan siapa yang akan terpilih untuk memenuhi jabatan khususnya pada divisi sales manager. Dalam proses penentuan jabatan ini dibutuhkan sebuah sistem pendukung keputusan. Dalam penyeleksian karyawan dengan menggunakan metode Profile Matching diperlukan kriteria-kriteria dan bobot untuk melakukan perhitungannya sehingga akan didapat alternatif terbaik (Dwijaya).

4. Sistem pendukung keputusan seleksi karyawan untuk penentuan jabatan tertentu dengan metode profile matching.

Seorang pengambil keputusan memiliki tanggung jawab untuk menentukan standar persyaratan yang dibutuhkan dalam menempatkan seseorang pada suatu jabatan tertentu berdasarkan aspek intelektual, aspek khusus serta aspek kompetensi manajerial orang tersebut dalam bekerja. Satu metode yang dapat digunakan dalam menyelesaikan permasalahan ini adalah dengan menggunakan metode profile matching, dimana profile matching merupakan metode pembantu bagi manajer untuk menempatkan seseorang pada posisi yang sedang kosong berdasarkan aspek intelektual, aspek khusus, serta aspek kompetensi manajerial (Suban, 2015).

Pada ke empat jurnal tersebut terdapat persamaan yaitu membahas mengenai sistem informasi yang membutuhkan suatu tujuan menggunakan sistem pendukung keputusan profile matching. Pada hal ini, penulis juga merancang bangun aplikasi pencarian pasangan kucing berbasis android. Namun, berbeda dengan keempat jurnal tersebut, aplikasi yang dirancang penulis membahas mengenai aplikasi pencarian pasangan kucing untuk komunitas cat lovers Kota Semarang. Aplikasi yang dirancang bangun ini memberikan informasi mengenai jenis ras kucing, informasi tentang profil kucing dan kesehatan kucing.

\subsection{Landasan Teori}

\section{A. Profile Matching}

Profil Matching adalah sebuah mekanisme pengambilan keputusan dengan mengasumsikan bahwa terdapat tingkat variabel prediktor yang ideal yang harus dipenuhi oleh subyek yang diteliti, bukannya tingkat minimal yang harus dipenuhi atau dilewati Dalam proses profile matching secara garis besar merupakan proses membandingkan antara kompetensi individu kedalam kompetensi kelompok sehingga dapat diketahui perbedaan kompetensinya (disebut juga gap), semakin kecil gap yang dihasilkan maka bobot nilainya semakin besar yang berarti memiliki peluang lebih besar untuk individu menempati posisi tersebut.

Adapun tahapan pada profile matching adalah :

1. Mulai dari menentukan bobot nilai gap. Pada tahap ini, akan ditentukan bobot nilai masingmasing aspek dengan menggunakan bobot nilai yang telah ditentukan bagi masingmasing aspek itu sendiri.

2. Langkah kedua dengan melakukan pemetaan Gap. Gap yang dimaksud adalah antara value atribut dan value target

$G A P=$ Value Atribut - Value Target

3. Setelah diperoleh Gap pada masing-masing profil, setiap profil diberi bobot nilai sesuai ketentuan pada tabel bobot nilai gap 
TABEl 2.1 Bobot Nilai GaP

\begin{tabular}{|c|c|c|c|}
\hline No & Selisih & $\frac{\text { Bobot }}{\text { Nilai }}$ & Keterangan \\
\hline 1 & 0 & 5 & $\begin{array}{l}\text { Tidak ada selisih (kompetensi sesuai } \\
\text { dengan yang dibutuhkan) }\end{array}$ \\
\hline 2 & 1 & 4,5 & Kompetensi individu kelebihan 1 tingkat \\
\hline 3 & -1 & 4 & Kompetensi individu kekurangan 1 tingkat \\
\hline 4 & 2 & 3,5 & Kompetensi individu kelebihan 2 tingkat \\
\hline 5 & -2 & 3 & Kompetensi individu kekurangan 2 tingkat \\
\hline 6 & 3 & 2,5 & Kompetensi individu kelebihan 3 tingkat \\
\hline 7 & -3 & 2 & Kompetensi individu kekurangan 3 tingkat \\
\hline 8 & 4 & 1,5 & Kompetensi individu kelebihan 4 tingkat \\
\hline 9 & -4 & 1 & Kompetensi individu kekurangan 4 tingkat \\
\hline
\end{tabular}

4. Melakukan perhitungan core factor dan secondary factor. Setelah menentukan bobot nilai gap untuk masing-masing aspek yang dibutuhkan, kemudian tiap aspek dikelompokan lagi menjadi dua kelompok yaitu core factor dan secondary factor.

Perhitungan core factor :

$N C F=\frac{\sum N C}{\sum I C}$

Keterangan :

NCF : Nilai rata-rata core factor

NC : Jumlah total nilai core factor

IC : Jumiah item core factor

Perhitungan secondary factor :

$N S F=\frac{\sum N S}{\sum I S}$

Keterangan :

NSF : Nilai rata-rata secondary factor

NS : Jumlah total nilai secondary factor

IS : Jumlah item secondary factor

5. Dari perhitungan setiap aspek yang diatas, berikutnya dihitung nilai total berdasarkan presentase dari core factor dan secondary factor yang diperkirakan berpengaruh terhadap masing-masing value. berikut :

Perhitungan nilai total dengan rumus sebagai

$((x) \% \times N C F)+((x) \% \times N S F)=N$

Keterangan :

NCF : Nilai rata-rata core factor

NSF : Nilai rata-rata secondary factor

$\mathrm{N} \quad$ : Nilai Total dari aspek- aspek penilaian

$(\mathrm{x}) \% \quad$ : Nilai Persen yang diinputkan

6. Hasil akhir dari proses Profile Matching adalah ranking dari kandidat yang diajukan. Setelah setiap kandidat mendapat hasil akhir, maka bisa ditentukan peringkat atau ranking dari kandidat berdasarkan pada semakin besarnya nilai hasil akhir sehingga semakin besar pula.

Perhitungan penentuan rangking dengan rumus sebagai berikut :

Ranking $=((x) \% \times N y)+((x) \% \times N z)$

Keterangan:

Ny : Nilai aspek y

$\mathrm{Nz}$ : Nilai aspek z

$(\mathrm{x}) \%$ : Nilai persen yang diinputkan
Profile matching merupakan mekanisme pengambilan keputusan dengan mengasumsikan bahwa terdapat tingkat variabel prediktor yang ideal yang harus dipenuhi oleh subyek yang diteliti, bukannya tingkat minimal yang harus dipenuhi atau dilewati (Setiyaningsih, 2012).

\section{B. Kucing}

Kucing adalah salah satu hewan peliharaan terpopuler di dunia. Kucing yang garis keturunannya tercatat secara resmi sebagai kucing trah atau galur murni (pure breed), seperti persia, siam, manx, dan sphinx. Kucing seperti ini biasanya dibiakkan di tempat pemeliharaan hewan resmi. Jumlah kucing ras hanyalah $1 \%$ dari seluruh kucing di dunia, sisanya adalah kucing dengan keturunan campuran seperti kucing liar atau kucing kampung.Jumlah ras kucing di seluruh dunia sangat banyak. Setiap ras memiliki ciri khusus, tetapi karena sering terjadinya kawin silang antar ras, banyak kucing yang hanya dikelompokkan dalam jenis bulu panjang dan bulu pendek, tergantung jenis rambut penutup tubuhnya. Jumlah Ras kucing yang sudah di data yaitu sebanyak 152 jenis kucing. Jenis kucing paling popular di Indonesia : Kucing Maine Coon, Kucing Siamese, Kucing Persia, Kucing Anggora, Kucing Sphynx, Kucing Asli Indonesia (Efendi, 2014).

\section{Java}

Java adalah bahasa pemrogramman yang dapat dijalankan di berbagai komputer termasuk telepon genggam. Bahasa ini awalnya dibuat oleh James Gosling saat masih bergabung di Sun Microsystems saat ini merupakan bagian dari Oracle dan dirilis tahun 1995. Bahasa ini banyak mengadopsi sintaksis yang terdapat pada $\underline{\mathrm{C}}$ dan $\underline{\mathrm{C}++}$ namun dengan sintaksis model objek yang lebih sederhana serta dukungan rutinrutin aras bawah yang minimal. Aplikasi-aplikasi berbasis java umumnya dikompilasi ke dalam pcode (bytecode) dan dapat dijalankan pada berbagai Mesin Virtual Java (JVM). Java merupakan bahasa pemrograman yang bersifat umum/non-spesifik (general purpose), dan secara khusus didisain untuk memanfaatkan dependensi implementasi seminimal mungkin. Karena fungsionalitasnya yang memungkinkan aplikasi java mampu berjalan di beberapa platform sistem operasi yang berbeda, java dikenal pula dengan slogannya, "Tulis sekali, jalankan di mana pun". Saat ini java merupakan bahasa pemrograman yang paling populer digunakan, dan secara luas dimanfaatkan dalam pengembangan berbagai jenis perangkat lunak aplikasi ataupun aplikasi (Kadir, 2014).

\section{RESTful AP}

RESTful API / REST API merupakan implementasi dari API (Application Programming Interface). REST (Representional State Transfer) adalah suatu arsitektur metode komunikasi yang menggunakan protokol HTTP untuk pertukaran data dan metode ini sering diterapkan dalam pengembangan aplikasi. Dimana tujuannya adalah untuk menjadikan sistem yang memiliki performa 
yang baik, cepat dan mudah untuk di kembangkan (scale) terutama dalam pertukaran dan komunikasi data (Haryandi, 2016).

RESTful API memiliki 4 komponen penting di dalamnya diantaranya adalah :
a) URL Design
b) HTTP Verbs
c) HTTP Response Code
d) Format Response

\section{E. UML(Unified Modelling Language)}

UML (Unified Modelling Language) adalah sebuah bahasa yang menjadi standar dalam industri untuk visualisasi, merancang dan mendokumentasikan system piranti lunak. Dengan menggunakan UML kita dapat membuat model untuk semua jenis aplikasi software, dimana aplikasi tersebut dapat berjalan pada hardware, sistem operasi dan jaringan apapun, serta ditulis dalam bahasa pemrograman apapun. Seperti bahasa-bahasa lainnya, UML mendefinisikan notasi dan syntax semantik. Notasi UML merupakan sekumpulan bentuk khusus untuk menggambarkan berbagai diagram piranti lunak. Setiap bentuk memiliki makna tertentu, dan UML syntax mendefinisikan bagaimana bentuk-bentuk tersebut dapat dikombinasikan.

\section{F. Metode Pengembangan Perangkat Lunak Multimedia Luther}

Metodologi pengembangan multimedia luther terdiri dari enam tahap, yaitu concept (pengkonsepan), design (pendesainan), material collecting (pengumpulan materi), assembly (pembuatan), testing (pengujian) dan distribution (pendistribusian). Keenam tahap ini tidak harus berurutan dalam praktiknya, tahap-tahap tersebut dapat saling bertukar posisi. Meskipun tahapnya dapat saling bertukar posisi, tetapi tahap pengkonsepan harus dikerjakan terlebih dahulu (Sutopo A. H., 2003).

\section{METODE PENELITIAN}

\section{A. Analisa Kebutuhan}

Analisia kebutuhan dapat diartikan sebagai proses mempelajari kebutuhan pemakai untuk mendapatkan definisi kebutuhan sistem atau perangkat lunak atau dapat juga diartikan sebagai proses untuk menetapkan fungsi dan unjuk kerja perangkat lunak, menyatakan antarmuka perangkat lunak dengan elemen-elemen system lain, dan menentukan kendala yang harus dihadapi oleh perangkat lunak.

\section{Membuat Konsep}

Tahap pembuatan konsep nantinya akan menggambarkan tujuan aplikasi, diantaranya termasuk identifikasi pengguna yaitu pemilik kucing, tujuan daripada pembuatan aplikasi dan spesifikasi umum dan dengan apa nantinya aplikasi tersebut dibuat.

\section{Perancangan Desain}

Tahap setelah analisa dari siklus pengembangan sistem adalah tahap perancangan sistem. Pada tahap perancangan sistem, mendefenisikan apa yang diperlukan dari kebutuhan sistem, melakukan persiapan untuk merancang bangun implementasi dan menggambarkan bagaimana suatu sistem dibentuk. Perancangan yang dilakukan terdiri dari perancangan database, interface dan pembagian hak akses terhadapat siapa saja user yang terkait pada aplikasi.

1) Perancangan Sistem (UML)

Merepresentasikan gambaran dari sistem yang dibuat dengan menggunakan notasi UML.

2) Perancangan Basis Data

Proses perancangan basis data ini adalah merancang kebutuhan tabel yang akan digunakan untuk penyimpanan data.

3) Perancangan Antar Muka

Merancang antar muka yang merupakan antar muka interaktif antara user dengan sistem.

\section{Pengumpulan Data}

Pada penelitian ini menggunakan teknik pengumpulan data dengan cara wawancara, kuesioner dan studi pustaka. Wawancara merupakan proses komunikasi yang sangat menentukan dalam proses penelitian. Dengan wawancara data yang diperoleh akan lebih baik, karena mampu menggali pemikiran atau pendapat secara detail. Wawancara tersebut dilakukan kepada Ketua Undip cat lovers Semarang, Drh.Arif Rahman, Staff Indonesian Assosiation Cat (ICA), dan Breeder PeternakanKucing.com sehingga didapatkan keterangan mengenai permasalahan yang dihadapi pada peneliatan ini. Selanjutnya pengumpulan data dengan kuisioner dilakukan dengan kelompok pecinta kucing yang berada di Semarang. Mengumpulkan data dengan studi pustaka, dengan cara mencari, mengumpulkan, mempelajari, menganalisa serta memahami literature-literature, seperti buku-buku, artikel, observasi, dokumen-dokumen.

1) Wawancara

Pada pembuatan aplikasi ini, pengumpulan data dilakukan melalui wawancara dan observasi langsung pada tempat dilaksanakannya penelitian.

2) Studi Pustaka

Penulis mengumpulkan teori dan pustaka yang berkaitan dengan metode profile matching, perkawinan kucing dan pemrograman android dan web service sebagai referensi untuk menyelesaikan masalah tersebut.

\section{Pembuatan Aplikasi}

Perancangan akan diimplementasikan dengan menggunakan java sebagai aplikasi web service, android sebagai aplikasi mobile dan basis data diimplementasikan dengan mysql.

\section{Pengujian}

Tahap selanjutnya adalah melakukan pengujian terhadap program yang telah dibuat 
dengan menggunakan pengujuian Black Box. Apabila pengujian gagal maka diperlukan adanya penelusuran kembali setiap perancangan yang telah dilakukan untuk menemukan penyebab kegagalan sampai tidak ada lagi error dalam aplikasi ini.

\section{Distribusi dan Pembuatan Laporan}

Setelah dilakukan ujicoba dan hasilnya sesuai. Maka langkah selanjutnya dilakukan distribusi dengan cara me-build kedalam format .apk dan diupload ke google drive dan Google PlayStore. Kemudian aplikasi ini dapat di implemantasikan secara luas di Undip cat lovers. Pembahasan dari hasil analisa yang telah dikerjakan dan kemudian penulisan laporan tugas akhir.

\section{B. Perancangan Proses}

Pada tahap perancangan proses ini, dibuat rancangan proses jalannya aplikasi pencarian pasangan kucing. Proses pada aplikasi pencarian pasangan kucing ini berupa flowchart.

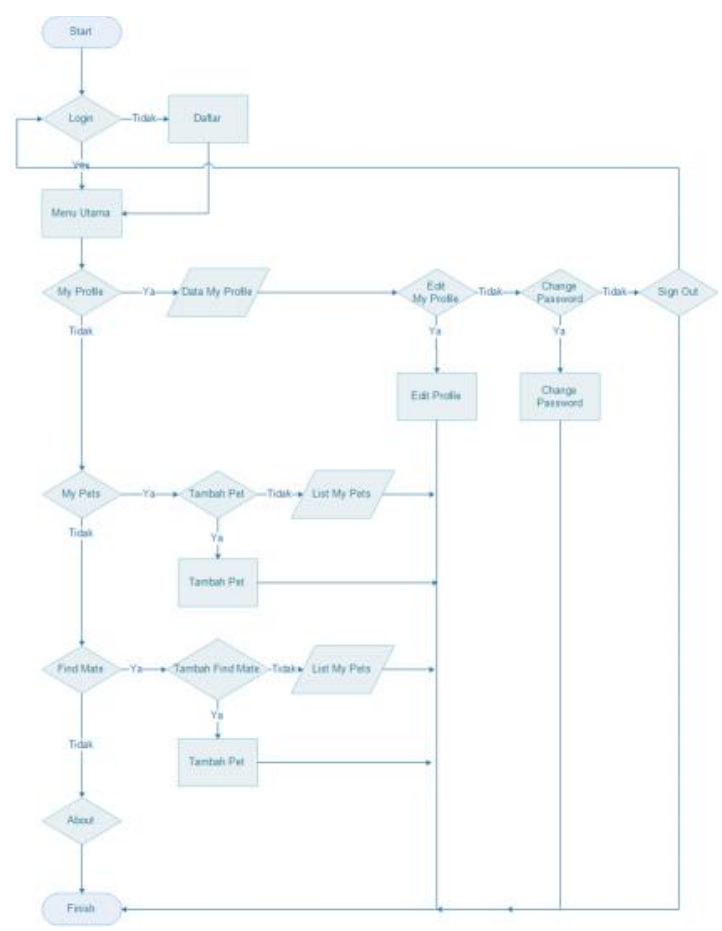

Gambar 3.1 Flowchart Utama ApLIKasI

Aplikasi pencarian pasangan kucing ini dimulai dari menu utama. Terdapat empat pilihan menu yaitu menu Find Mate, menu My Profile, My Pets dan menu About. Pada menu Find Mate menampilkan proses pencarian pasangan kucing. Pada menu My Profile menampilkan informasi tentang user Pada menu My Profile menampilkan informasi tentang kucing yang dimiliki dan pada menu about menampilkan informasi singkat mengenai aplikasi dna proses yang berjalan pada find mate.

\section{Perancangan Profile Matching}

Pada perancangan penelitian untuk aplikasi ini menggunakan penerapan dari metode Profile
Matching. Metode Profile Matching adalah metode yang mengambil keputusan dengan mengasumsikan bahwa terdapat tingkat variable predictor yang ideal yang harus dimiliki oleh profile lawan, bukanya tingkat minimal yang harus dipenuhi atau dilewati.

Adapun tahapan pada profile matching adalah :

1. Mulai dari menentukan bobot nilai gap. Pada tahap ini, akan ditentukan bobot nilai masingmasing aspek dengan menggunakan bobot nilai yang telah ditentukan bagi masingmasing aspek itu sendiri. Adapun inputan dari proses pembobotan ini adalah selisih dari profil kucing jantan dan kucing betina. Dalam kasus ini, dicontohkan 2 aspek penilaian yang digunakan, yaitu:

1) Aspek Ideal, yang memiliki 2 faktor

a) Berat badan

Sesuai dengan hasil riset bahwa prosedur perkawinan kucing menurt Dokter hewan berat badan kucing yang paling baik untuk ideal kucing yang akan dikawinkan dari tertinggi sampai terendah yaitu $2.8 \mathrm{Kg}-3 \mathrm{Kg}, 3 \mathrm{Kg}-3.5 \mathrm{Kg}, 2 \mathrm{Kg}-2.8$, diatas $3.5 \mathrm{Kg}$ dan dibawah $2 \mathrm{Kg}$.

Skala Penilaian :

TABel 3.1 Skala Berat Badan

\begin{tabular}{|l|l|l|}
\hline No & Skala & Nilai \\
\hline $\mathbf{1}$ & $2,8 \mathrm{Kg}-3 \mathrm{Kg}$ & 5 \\
\hline $\mathbf{2}$ & $3 \mathrm{Kg}-3,5 \mathrm{Kg}$ & 4 \\
\hline $\mathbf{3}$ & $2 \mathrm{Kg}-2,8 \mathrm{Kg}$ & 3 \\
\hline $\mathbf{4}$ & Lebih dari $3,5 \mathrm{Kg}$ & 2 \\
\hline $\mathbf{5}$ & Kurang dari $2 \mathrm{Kg}$ & 1 \\
\hline
\end{tabular}

b) Umur

Sesuai dengan hasil riset bahwa prosedur perkawinan kucing menurt Dokter hewan umur kucing yang paling baik untuk ideal kucing yang akan dikawinkan dari tertinggi sampai terendah yaitu 1 tahun - 3 tahun, 3 tahun -5 tahun, 10 bulan-12 bulan, diatas 5 tahun dan dibawah 1 Tahun.

Skala Penilaian :

TABEL 3.2 SKALA UMUR

\begin{tabular}{|l|l|l|}
\hline No & Skala & Nilai \\
\hline $\mathbf{1}$ & 1 Tahun -3 Tahun & 5 \\
\hline $\mathbf{2}$ & 3 Tahun -5 Tahun & 4 \\
\hline $\mathbf{3}$ & 10 Bulan - 12 Bulan & 3 \\
\hline $\mathbf{4}$ & Diatas 5 Tahun & 2 \\
\hline $\mathbf{5}$ & Dibawah 10 Bulan & 1 \\
\hline
\end{tabular}

2) Aspek Kesehatan, yang memiliki 2 faktor

a) Vaksin

Sesuai dengan hasil riset bahwa prosedur perkawinan kucing menurut Dokter hewan, pemberian vaksin yang paling baik untuk kucing yang akan dikawinkan dari tertinggi sampai terendah yaitu Rutin 1 tahun sekali, 1.5 tahun sekali, 2 tahun sekali, 3 tahun sekali, belum pernah vaksin 
Tabel 3.3 Skala Penilaian Berapa Kal VaKsin

\begin{tabular}{|l|l|l|}
\hline No & Skala & Nilai \\
\hline $\mathbf{1}$ & Rutin 1 Tahun sekali & 5 \\
\hline $\mathbf{2}$ & 1,5 Tahun sekali & 4 \\
\hline $\mathbf{3}$ & 2 Tahun sekali & 3 \\
\hline $\mathbf{4}$ & 2,5 Tahun sekali & 2 \\
\hline $\mathbf{5}$ & Dibawah 10 Bulan & 1 \\
\hline
\end{tabular}

b) Obat Cacing

Sesuai dengan hasil riset bahwa prosedur perkawinan kucing menurut Dokter hewan, pemberian obat cacing yang paling baik untuk kucing yang akan dikawinkan dari tertinggi sampai terendah yaitu Rutin tiap 3 bulan, 3 bulan terakhir, 6 bulan terakhir, 9 bulan terakhir, 12 bulan terakhir. Skala Penilaian :

Tabel 3.4 Skala Penilaian Pemberian Obat Cacing

\begin{tabular}{|l|l|l|}
\hline No & Skala & Nilai \\
\hline $\mathbf{1}$ & Rutin 3 Bulan sekali & 5 \\
\hline $\mathbf{2}$ & 3 Bulan terakhir & 4 \\
\hline $\mathbf{3}$ & 6 Bulan terakhir & 3 \\
\hline $\mathbf{4}$ & 9 Bulan terakhir & 2 \\
\hline $\mathbf{5}$ & Lebih dari 1 Tahun & 1 \\
\hline
\end{tabular}

Berikut adalah contoh perhitungan yang digunakan dalam sistem yang sedang dikembangkan. Data kucing yang akan dipasangkan dan data kucing yang ada dalam aplikasi tersebut data sebagai berikut:

TABel 3.5 NILAI Kriteria Profil KuCING

\begin{tabular}{|c|c|c|c|c|c|c|}
\hline \multirow[b]{2}{*}{ No } & \multirow{2}{*}{\begin{tabular}{|l|} 
Nama \\
Kucing
\end{tabular}} & \multicolumn{5}{|c|}{ Penilaian Kriteria } \\
\hline & & Ras & Umur & $\begin{array}{l}\text { Berat } \\
\text { Badan }\end{array}$ & Vaksin & $\begin{array}{l}\text { Obat } \\
\text { Cacing }\end{array}$ \\
\hline 1 & Ciko & $\begin{array}{l}\text { Persia } \\
\text { Himalaya }\end{array}$ & 5 & 5 & 3 & 3 \\
\hline 2 & Lico & Persia & 5 & 3 & 3 & 2 \\
\hline 3 & Cindy & Persia & 3 & 1 & 4 & 3 \\
\hline 4 & Popo & $\begin{array}{l}\text { Persia } \\
\text { Himalaya }\end{array}$ & 4 & 5 & 1 & 3 \\
\hline 5 & Gondes & Exo & 5 & 5 & 3 & 1 \\
\hline
\end{tabular}

Dengan data kucing yang akan dipasangkan

TABEL 3.6 NILAI KRITERIA KUCING TARGET

\begin{tabular}{|l|l|l|l|l|l|l|}
\hline \multirow{2}{*}{ No } & $\begin{array}{l}\text { Nama } \\
\text { Kucing }\end{array}$ & Ras & \multicolumn{3}{|c|}{ Penilaian Kriteria } \\
\cline { 2 - 5 } & Umur & $\begin{array}{l}\text { Berat } \\
\text { Badan }\end{array}$ & Vaksin & $\begin{array}{l}\text { Obat } \\
\text { Cacing }\end{array}$ \\
\hline $\mathbf{1}$ & Milo & Persia & 5 & 3 & 4 & 4 \\
\hline
\end{tabular}

2. Langkah kedua dengan melakukan pemetaan Gap. Gap yang dimaksud adalah antara value atribut dan value target

GAP $=$ Value Atribut - Value Target

\begin{tabular}{|c|c|c|c|c|c|c|c|}
\hline \multirow[b]{2}{*}{ No } & \multirow[b]{2}{*}{$\begin{array}{l}\text { Nama } \\
\text { Kucing }\end{array}$} & \multirow[b]{2}{*}{ Ras } & \multicolumn{5}{|c|}{ Penilaian Kriteria } \\
\hline & & & Umur & $\begin{array}{l}\text { Berat } \\
\text { Badan }\end{array}$ & Vaksin & $\begin{array}{l}\text { Obat } \\
\text { Cacing }\end{array}$ & \\
\hline 1 & Ciko & Persia Himalaya & 5 & 5 & 3 & 3 & \multirow{5}{*}{ Nilai } \\
\hline 2 & Lico & Persia & 5 & 3 & 3 & 2 & \\
\hline 3 & Cindy & Persia & 3 & 1 & 4 & 3 & \\
\hline 4 & Popo & Persia Himalaya & 4 & 5 & 1 & 3 & \\
\hline \multirow[t]{2}{*}{5} & Gondes & Exo & 5 & 5 & 3 & 1 & \\
\hline & Milo & Persia & 5 & 3 & 4 & 4 & \\
\hline 1 & Ciko & Persia Himalaya & 0 & 2 & -1 & -1 & \multirow{5}{*}{ GAP } \\
\hline 2 & Lico & Persia & 0 & 0 & -1 & -2 & \\
\hline 3 & Cindy & Persia & -2 & -2 & 0 & -1 & \\
\hline 4 & Popo & Persia Himalaya & -1 & 2 & -3 & -1 & \\
\hline 5 & Gondes & Exo & 0 & 2 & -1 & -3 & \\
\hline
\end{tabular}

3. Melakukan pencocokan dengan table bobot gap hasil dari pengurangan Profile Pets Source Profile Pets Target bila dicocokan dengan selisih gap pada table bobot nilai yang dihasilkan sama. Tabel bobot nilai bisa dilihat pada table berikut

TABEL 3.8 BOBOT NilAi GAP

\begin{tabular}{|c|c|c|c|}
\hline No & Selisih & $\begin{array}{l}\text { Bobot } \\
\text { Nilai }\end{array}$ & Keterangan \\
\hline 1 & 0 & 5 & $\begin{array}{l}\text { Tidak ada selisih (kompetensi sesuai } \\
\text { dengan yang dibutuhkan) }\end{array}$ \\
\hline 2 & 1 & 4,5 & Kompetensi individu kelebihan 1 tingkat \\
\hline 3 & -1 & 4 & $\begin{array}{l}\text { Kompetensi individu kekurangan } 1 \\
\text { tingkat }\end{array}$ \\
\hline 4 & 2 & 3,5 & Kompetensi individu kelebihan 2 tingkat \\
\hline 5 & -2 & 3 & $\begin{array}{l}\text { Kompetensi individu kekurangan } 2 \\
\text { tingkat }\end{array}$ \\
\hline 6 & 3 & 2,5 & Kompetensi individu kelebihan 3 tingkat \\
\hline 7 & -3 & 2 & $\begin{array}{l}\text { Kompetensi individu kekurangan } 3 \\
\text { tingkat }\end{array}$ \\
\hline 8 & 4 & 1,5 & Kompetensi individu kelebihan 4 tingkat \\
\hline 9 & -4 & 1 & $\begin{array}{l}\text { Kompetensi individu kekurangan } 4 \\
\text { tingkat }\end{array}$ \\
\hline
\end{tabular}

TABel 3.9 Hasil Pembobotan NILAI

\begin{tabular}{|c|c|c|c|c|c|c|c|}
\hline \multirow[b]{2}{*}{ No } & \multirow[b]{2}{*}{$\begin{array}{l}\text { Nama } \\
\text { Kucing }\end{array}$} & \multirow[b]{2}{*}{ Ras } & \multicolumn{4}{|c|}{ Penilaian Kriteria } & \\
\hline & & & Umur & $\begin{array}{l}\text { Berat } \\
\text { Badan }\end{array}$ & Vaksin & $\begin{array}{l}\text { Obat } \\
\text { Cacing }\end{array}$ & \\
\hline 1 & Ciko & Persia Himalaya & 5 & 5 & 3 & 3 & \multirow{5}{*}{ Nilai } \\
\hline 2 & Lico & Persia & 5 & 3 & 3 & 2 & \\
\hline 3 & Cindy & Persia & 3 & 1 & 4 & 3 & \\
\hline 4 & Popo & Persia Himalaya & 4 & 5 & 1 & 3 & \\
\hline \multirow[t]{2}{*}{5} & Gondes & Exo & 5 & 5 & 3 & 1 & \\
\hline & Milo & Persia & 5 & 3 & 4 & 4 & \\
\hline 1 & Ciko & Persia Himalaya & 0 & 1 & -1 & 0 & \multirow{5}{*}{ GAP } \\
\hline 2 & Lico & Persia & 0 & -1 & -1 & -1 & \\
\hline 3 & Cindy & Persia & -2 & -3 & 0 & 0 & \\
\hline 4 & Popo & Persia Himalaya & -1 & 1 & -3 & 0 & \\
\hline 5 & Gondes & Exo & 0 & 1 & -1 & 2 & \\
\hline \multicolumn{8}{|c|}{ Hasil pembootan } \\
\hline 1 & Ciko & Persia Himalaya & 5 & 3.5 & 4 & 4 & \multirow{5}{*}{$\begin{array}{l}\text { Bobot } \\
\text { Nilai }\end{array}$} \\
\hline 2 & Lico & Persia & 5 & 5 & 4 & 3 & \\
\hline 3 & Cindy & Persia & 3 & 3 & 5 & 4 & \\
\hline 4 & Popo & Persia Himalaya & 4 & 3.5 & 2 & 4 & \\
\hline 5 & Gondes & Exo & 5 & 3.5 & 4 & 2 & \\
\hline
\end{tabular}

4. Melakukan perhitungan core factor dan secondary factor. Setelah menentukan bobot nilai gap untuk masing-masing aspek yang dibutuhkan, kemudian tiap aspek dikelompokan lagi menjadi dua kelompok yaitu core factor dan secondary factor.

Perhitungan core factor :

$N C F=\frac{\sum N C}{\sum I C}$

Keterangan :

NCF : Nilai rata-rata core factor

NC : Jumlah total nilai core factor

IC : Jumlah item core factor 
Perhitungan secondary factor :

$N S F=\frac{\sum N S}{\sum I S}$

Keterangan :

NSF : Nilai rata-rata secondary factor

NS : Jumlah total nilai secondary factor

IS : Jumlah item secondary factor

TABEL 3.10 HASIL NILAI CF DAN SF ASPEK IDEAL

\begin{tabular}{|l|c|c|}
\hline $\begin{array}{l}\text { Nama } \\
\text { Kucing }\end{array}$ & $\begin{array}{c}\text { CoreFactor } \\
\text { (Umur) }\end{array}$ & $\begin{array}{c}\text { Secondary } \\
\text { Factor } \\
\text { (Berat } \\
\text { Badan) }\end{array}$ \\
\hline Ciko & 5 & 3.5 \\
\hline Lico & 5 & 5 \\
\hline Cindy & 3 & 3 \\
\hline Popo & 4 & 3.5 \\
\hline Gondes & 5 & 3.5 \\
\hline
\end{tabular}

TABEL 3.11 HASIL NILAI CF dAN SF ASPEK KESEHATAN

\begin{tabular}{|l|c|c|}
\hline Kucing & $\begin{array}{c}\text { Core Factor } \\
\text { (Vaksin) }\end{array}$ & $\begin{array}{c}\text { Secondary } \\
\text { Factor }\end{array}$ \\
(Obat Cacing)
\end{tabular}

5. Dari perhitungan setiap aspek yang diatas, berikutnya dihitung nilai total berdasarkan presentase dari core factor dan secondary factor yang diperkirakan berpengaruh terhadap masing-masing value. berikut :

Perhitungan nilai total dengan rumus sebagai

$((x) \% \times N C F)+((x) \% \times N S F)=N$

Keterangan :

NCF : Nilai rata-rata core factor

NSF : Nilai rata-rata secondary factor

$\mathrm{N}$ : Nilai Total dari aspek- aspek penilaian

$(\mathrm{x}) \%$ : Nilai Persen yang diinputkan, nilai sesuai dengan hasil wawancara

TABel 3.12 HASIL NILAI TOtAL ASPEK IDEAL

\begin{tabular}{|l|c|c|c|}
\hline $\begin{array}{c}\text { Nama } \\
\text { Kucing }\end{array}$ & $\begin{array}{c}\text { CoreFactor } \\
\text { (Umur) }\end{array}$ & $\begin{array}{c}\text { Secondary Factor } \\
\text { (Berat Badan) }\end{array}$ & $\begin{array}{c}\text { Nilai Total } \\
\text { (Core*50\%+ } \\
\text { Second50\%) }\end{array}$ \\
\hline Ciko & 5 & 3.5 & 4.25 \\
\hline Lico & 5 & 5 & 5 \\
\hline Cindy & 3 & 3 & 3 \\
\hline Popo & 4 & 3.5 & 3.75 \\
\hline Gondes & 5 & 3.5 & 4.25 \\
\hline
\end{tabular}

Tabel 3.13 Hasil Nilai Total Aspek Kesehatan

\begin{tabular}{|l|c|c|c|} 
Kucing & $\begin{array}{l}\text { Core Factor } \\
\text { (Vaksin) }\end{array}$ & $\begin{array}{l}\text { Secondary } \\
\begin{array}{l}\text { Factor } \\
\text { (Obat Cacing) }\end{array}\end{array}$ & $\begin{array}{l}\text { Nilai Total } \\
\left.\text { (Core5\%+Second }{ }^{\star} 50 \%\right)\end{array}$ \\
\hline Ciko & 4 & 4 & 4 \\
\hline Lico & 4 & 3 & 3.5 \\
\hline Cindy & 5 & 4 & 4.5 \\
\hline Popo & 2 & 4 & 3 \\
\hline Gondes & 4 & 2 & 3 \\
\hline
\end{tabular}

6. Hasil akhir dari proses Profile Matching adalah ranking dari kandidat yang diajukan. Setelah setiap kandidat mendapat hasil akhir, maka bisa ditentukan peringkat atau ranking dari kandidat berdasarkan pada semakin besarnya nilai hasil akhir sehingga semakin besar pula.

Perhitungan penentuan rangking dengan rumus sebagai berikut :

Ranking $=((x) \% \times N y)+((x) \% \times N z)$

Keterangan:

Ny : Nilai aspek ideal

$\mathrm{Nz}$ : Nilai aspek kesehatan

$(\mathrm{x}) \%$ : Nilai persen yang diinputkan, nilai sesuai dengan hasil wawancara

TABEL 3.14 HASIL RANKING

\begin{tabular}{|l|l|}
\hline Kucing & Ranking \\
\hline Lico & 4.40 \\
\hline Ciko & 4.15 \\
\hline Gondes & 3.75 \\
\hline Cindy & 3.60 \\
\hline Popo & 3.45 \\
\hline
\end{tabular}

Jadi pasangan untuk kucing Milo sistem menyarankan bahwa Lico yang menjadi prioritas.

\section{HASIL DAN ANALISA}

\subsection{Hasil Perancangan}

Aplikasi yang dibangun adalah aplikasi pencarian pasangan kucing berbasis android dengan menggunakan android studio. Aplikasi ini dirancang untuk memenuhi kebutuhan pemilik kucing akan informasi kucing peliharaanya yang akan dicarikan pasangan. Dalam aplikasi ini bukan hanya menampilkan informasi mengenai proses pencarian pasangan kucing aplikasi ini juga menjelaskan tentang nilai dari kesehatan kucing yang akan dicarikan pasanganya. Dalam aplikasi ini, terdapat beberapa pilihan alternatif pasangan kucing yang nantinya dapat dipilih oleh pengguna sesuai dengan keinginan masing-masing pengguna. Selain mempermudah para pengguna dalam pencarian pasangan kucing, aplikasi ini juga dapat berbagi informasi oleh sesama pemilik kucing. Resiko salah memilih pasangan kucing juga dapat dihindari dengan menggunakan aplikasi ini.

\section{Halaman Menu Awal}

Tampilan menu awal ini adalah halaman yang terdapat menu sign in dan register yang sesuai dengan perancangan interface.

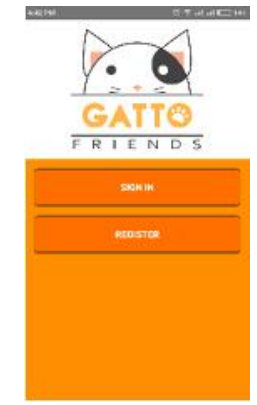

Gambar 4.1 Halaman Menu Awal AplikasI 


\section{Halaman Sign In}

Tampilan Sign In ini dimana user harus menginputakan email dan password yang sudah terdaftar, jika sign in berhasil maka akan masuk halaman my profile. Berikut tampilan sign in yang sesuai dengan perancangan interface :

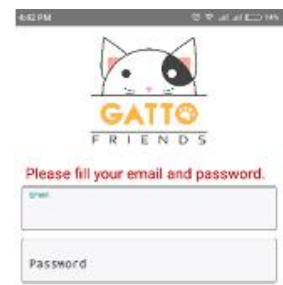

GAMBAR 4.2 TAMPILAN SIGN IN APLIKASI

\section{Halaman Register}

Tampilan Register ini dimana user harus mengisi form yang sudah tersedia dan user dengan me-klick button register berarti user telah menyetujui Terms and Privacy Policy aplikasi Gatto Friends. Berikut tampilan sign in yang sesuai dengan perancangan interface :

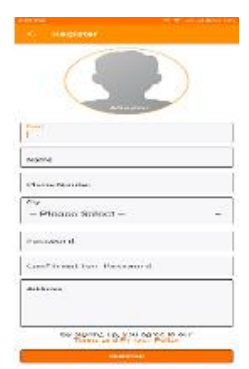

Gambar 4.3 TAmPILAN REgISTER

\section{Halaman My Profile}

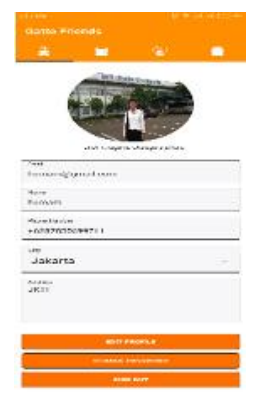

Gambar 4.4 Tampilan Menu My Profile

Pada gambar 4.6 adalah halaman untuk menampilkan menu my profile, dimana user dapat melihat identitas diri yang sudah didaftarkan dan terdapat menu edit profile, change password dan sign out

\section{Halaman Menu My Pets}

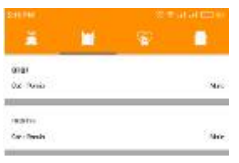

Gambar 4.5 TAmpilan Menu My PetS

Pada Gambar 4.5 mejelaskan tentang tampilan menu my pets, dimana terdapat button tambah untuk menambah pets yang user miliki dan jika user sudah memiliki pets yang sudah terdaftar pets akan muncul dalam bentuk list.

\section{Halaman Menu Detail My Pets}

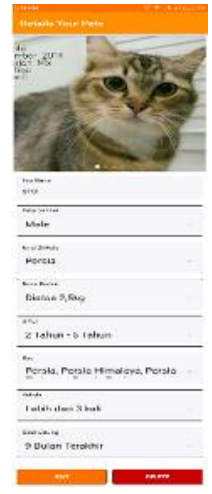

Gambar 4.6 Tampilan Detall My PetS

Pada Gamabar 4.6 menejelaskan tampilan detail my pets dimana terdapat informasi lengkap tentang pets yang user miliki secara detail dan juga terdapat button untuk mengubah data pets dan menghapus pets.

\section{Halaman Find Mate}

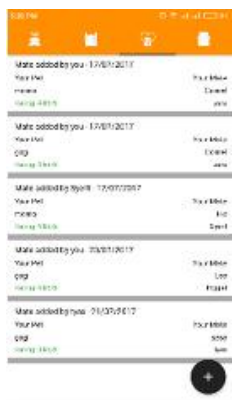

Gambar 4.7 halaman FIND MATE

Pada Gambar 4.7 Menjelaskan tentang tampilan find mate, dimana user dapat mencarikan pasangan kucingnya jika user sudah pernah melakukan find mate history mate akan terlihat 
dalam bentuk list dan jika user belum pernah melakukan find mate user dapat menekan button tambah pada pojok bawah kiri untuk mencari pasangan kucing.

\section{Halaman Select Your Pets}

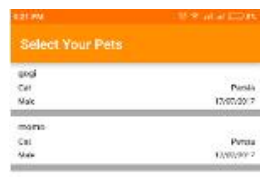

\section{Gambar 4.8 Halaman Select Your Pets}

Pada Gambar 4.8 menjelaskan tentang tampilan select your pets, dimana user memilih kucing yang akan dicarikan pasangannya.

\section{Halaman Hasil Find Mate}

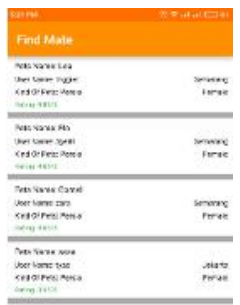

Gambar 4.9 Halaman Hasil Find Mate

Pada Gambar 4.9 Menjelaskan tentang tampian hasil find mate, yang akan menampilkan hasil find mate dalam bentuk list, yang berisi target pets yang akan dipilih.

\section{Halaman Details Pets Target}

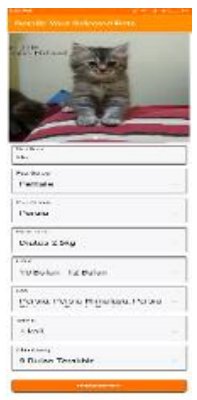

Gambar 4.10 halaman Details Selected Your Pets

Pada Gambar 4.10 menjelaskan tentang tampilan details selected your pets, dimana menjelaskan tentang informasi detail kucing yang sudah dipilh sebagai pets source, dan terdapat button communicate untuk chat dengan pemilik kucing tersebut.

\section{Halaman Chatting}
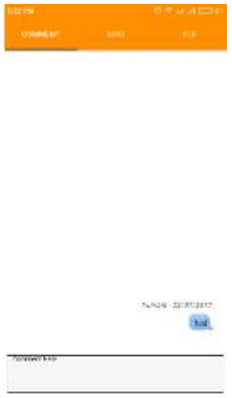

Gambar 4.11 halaman Communicate

Pada halaman communicate user dapat dengan langsug berhubungan dengan pemilik pets target dengan chatting, pada halaman communicate juga menampilkan detail informasi kucing milik pengguna dan pemilik kucing lain yang akan dipasangkan.

\section{Halaman Details Pets Target}

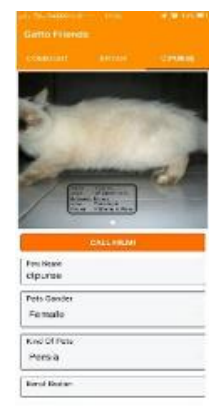

Gambar 4.12 Detalls Pets TARget

Pada Gambar 4.12 menjelaskan tentang tampilan details pets target, dimana pada halaman tersebut menjelaskan tentang informasi tentang kucing milik user lain agar dapat dengan mudah membandingkan dengan kucing milik pengguna dan juga terdapat button call untuk menghbungi user.

\section{Halaman About}

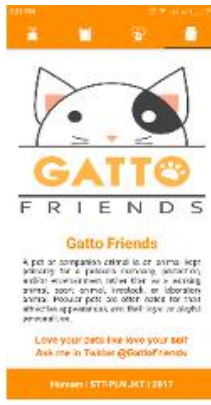

Gambar 4.13 HaLAmAN ABOUT

Pada gambar 4.13 menjelaskan tentang tampilan about dimana terdapat contact person untuk aplikasi 


\section{Halaman Sign in Admin}

Pada halaman sign in admin terdapat inputan username dan email admin jika email dan password benar maka admin dapat mengakses data user dan pets pada aplikasi.

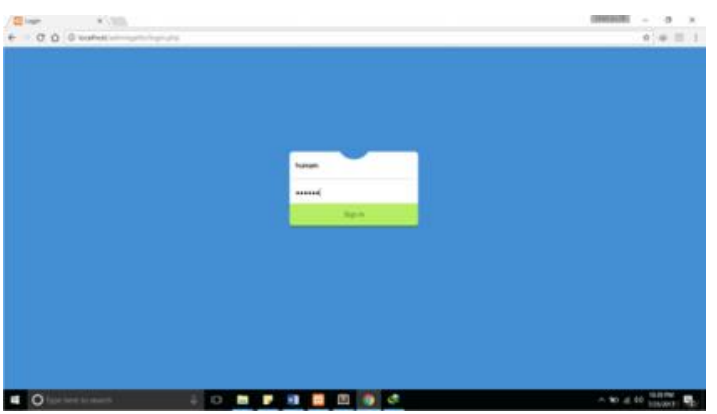

Gambar 4.14 HALAMAN SIGN IN ADMIN

\section{Halaman Tabel List User}

Berikut interface dari hasil perancangan di bab sebelumnya untuk halaman table list user yang berisi data user Gatto Friends yang berisi seperti username, email, nomor handphone dan menu action :

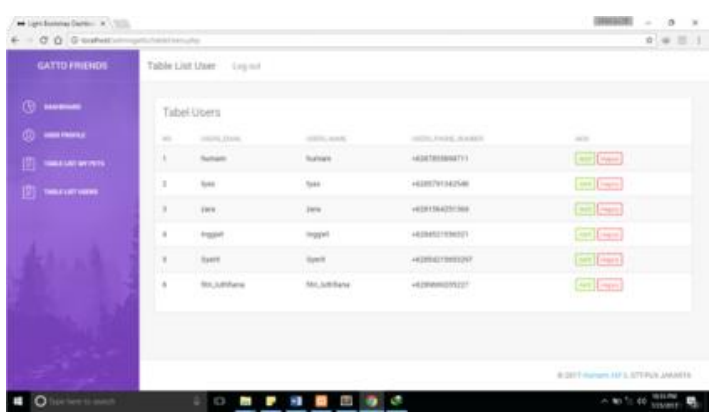

Gambar 4.15 halaman Tabel List USER

\subsection{Pembahasan Aplikasi}

Aplikasi Gatto Friends ini dibuat berdasarkan metode Luther sehingga dibuat lebih untuk tampilan yang lebih user friendly. Dengan sistem online yang memudahkan user untuk menggunakan aplikasi dimana saja. Aplikasi Gatto Firends yang dibangun berfungsi untuk mengatasi pencarian pasangan kucing dengan factor dasar kesehatan dan kondisi kucing yang sudah ideal untuk dicarikan pasangan dikarenakan masih banyak pemilihan kucing yang tidak menganut aturan tersebut dan juga aplikasi ini memudahkan pemilik kucing untuk saling mengetahui siapa saja yang memiliki kucing dengan jenis ras yang sama.

Sebelumnya aplikasi pencarian pasangan kucng ini sudah pernah ada, system yang digunakan masih random atau pengguna aplikasi mendapatkan pasangan tidak dengan melihat dari factor kesehatan maupun ideal kucing tersebut. Akan tetapi dengan masih menggunakan system tersebut, penulis melakukan wawancara kepada pihak terkait sehingga penulis membuat system yang mempermudah sesuai dengan perkembangan zaman saat ini. Sebagaimana keterangan tabel dibawah ini :
Tabel 4. 1 Perbedaan Sistem Lama dengan Sistem Baru

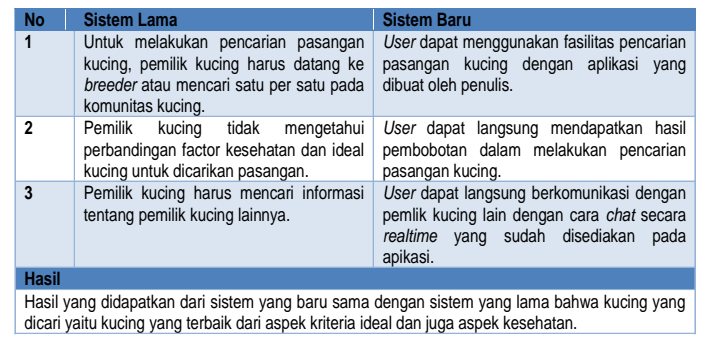

\subsubsection{Kelebihan dan Kekurangan Aplikasi}

Aplikasi yang dibangun oleh penulis belum sempurna mengingat ilmu penulis berharap adanya masukan untuk penulis. Dibawah ini akan dijelaskan kelebihan dan kekurangan aplikasi berdasarkan hasil pengujian dan kuisioner (terlampir) :

1. Kelebihan

a. Mampu mencarikan pasangan kucing dengan prediksi yang tinggi berdasarkan factor kesehatan dan ideal kucing yang akan dicarikan pasangan.

b. Tidak menyulitkan pengguna mencari informasi kontak yang bisa dihubungi karena ada fasilitas chat real time.

c. Dapat melihat tingkat ideal kucing yang dimiliki user.

2. Kekurangan

User harus selalu mengecek aplikasi karena belum adanya fitur notifikasi

\section{KESIMPULAN DAN SARAN}

\subsection{Kesimpulan}

Berdasarkan uraian pada bab-bab sebelumnya maka penulis dapat mengambil kesimpulan sebagai berikut :

1. Pemilik kucing mendapatkan informasi kucing lawan dengan lengkap, karena adanya fitur chatting yang terdapat pada aplikasi Gatto Friends.

2. Aplikasi Gatto Friends dirancang dengan bahasa pemograman java, perancangan sistem dengan menggunakan unified modeling language

3. Dengan menggunakan metode pengembangan sistem multimedia luther didapatkan hasil perhitungan kuisioner, aplikasi Gatto Friends mudah digunakan dengan presentase $100 \%$ dari total 10 responden. Fungsi aplikasi berjalan 100\% sehingga dapat mengurangi resiko kesalahan perkawinan kucing dan aplikasi ini layak digunakan untuk komunitas lainya.

4. Dengan menggunakan aspek kesehatan dan aspek ideal kucing dalam perkawinan untuk pembobota kucing jantan dan kucing betina, sehingga nilai yang dirangkingkan menjadikan prediksi yang cukup akurat, maka metode Profile Matching efektif digunakan untuk mencarikan pasangan kucing. 


\subsection{Saran}

1. Aplikasi ini hanya dapat melakukan pencarian pasangan kucing berdasar jenis tertentu Persia, Exo, Bengal, Mainecoon, Domestik, Spyhnx. diharapkan untuk pengembangan dapat mencarikan pasangan semua jenis kucing.

2. Pengembangan aplikasi ini diharapkan mampu memberikan data yang mudah diupdate sewaktu-waktu oleh pihak-pihak yang terkait.

3. Aplikasi ini dapat memberikan notifikasi ketika terdapat kucing yang akan dikawinkan.

\section{DAFTAR PUSTAKA}

Angkasa, S. (2016). Penerapan metode profile matching untuk memberikan kelayakan pemberian kredit pada pnpm mandiri kota Banjarmasin. urnal Teknologi Informasi, 36-37.

Bunafit, N. (2006). Database Relasional dengan MySql. Andi.

Dwijaya, I. F. (n.d.). sistem pendukung keputusan kenaikan jabatan pada PT.SYSMEX menggunakan metode profile matching. 1-2.

Efendi, C. (2014). Kucing. Jakarta.

Ensiklopedi Indonesia. (1988). Jakarta.

Fernando, Y. Y. (2013). Sistem Pendukung Keputusan Seleksi Pelamar Berdasarkan Psikogram Dengan Metode Profile Matching .

Haryandi, S. (2016). MENGENAL RESTFUL API.

Kadir, A. (2014). Pemogramman Java. Yogyakarta: Mediakom.

Mariandayani, H. N. (2012). Keragaman Kucing Domestik(felis domesticus) berdasarkan Morfogenetik . Jurnal Peternakan Sriwijaya (JPS) .

O'Docherty, M. (2005). Object-Oriented Analysis and Design Understanding System Development with UML 2.0. England: John Wiley \& Sons Ltd.
PLN, S. T. (2015). Pedoman Penyusunan Penulisan Proposal Penelitian. Jakarta.

Rosa, S. A. (2015). Rekayasa Perangkat Lunak Terstruktur dan Berorientasi Objek. Jakarta: Informatika.

Safaat, N. H. (2014). Android Pemograman Aplikasi Mobile Smartphone dan Tablet. Bandung: Informatika.

Setiyaningsih, W. (2012). Modul Ajar Profile Matching Universitas Kanjuruhan Malang. .

Sigi, A. L. (2015). Perancangan Aplikasi Sarana Dan Rumah Tangga Laboratorium . Jakarta.

Suban, S. (2015). SISTEM PENDUKUNG KEPUTUSAN SELEKSI KARYAWAN UNTUK PENENTUAN . Sistem Informasi, 2-3.

Sukma, E. (2015). RANCANG BANGUN APLIKASI FORUM KOMUNITAS BERBASIS WEB .

Suri, P. (2015, Agustus). Retrieved from Masa Hamil Kucing: http://www.cattery.co.id/berapalama-kucing-hamil-berikut-masa-hamil-kucing/

Sutopo, A. (2003). Metode Pengembangan Multimedia. Jakarta : Graha IImu.

Sutopo, A. H. (2003). Multimedia Interaktif dengan Flash. Yogyakarta: Graha IImu.

Tohari, H. (2014). Astah- Analisis Serta Perancangan Sistem Informasi Melalui Pendekatan UML. Jakarta: Andi Publisher.

Turban, E. (2004). Decision Support Systems and Intelligent Systems 7th Edition. 